\title{
Medicolegal Approach of a Scald Burn Case in the School
}

\author{
Okul Kazasına Bağlı Bir Yanık Olgusunda Adli-tıbbi Değerlendirme
}

\author{
(D) Ahsen Kaya, (D) Uğur Ata, (D) Hülya Güler, (D) Ender Şenol, (D) Ekin Özgür Aktaş \\ Ege University Faculty of Medicine, Department of Forensic Medicine, Izmir, Turkey
}

\section{Abstract}

The school environment is the place where children mostly are away from parental supervision for the first time and for a long period of time. Children may be injured by accidents like burns at the school. Thus, making them vulnerable when security measures are not taken accordingly. This study aimed to discuss the trauma severity and medicolegal aspects of a scald injury in the school. This is a case of a 7-year-old male who had burn injury by spilling hot water at the school canteen with a medicolegal perspective by related literature. A second degree burn that covers about 30\% of his body surface was determined in his first medical records. Sepsis and renal insufficiency had been developed in the process. Three years after the accident, his tissue losses and psychological symptoms due to the accident were examined for his forensic report. Findings conspicuously showed that accidents might cause permanent physical and psychological damages in individuals, their families and also significant costs for the society. Accidents and their negative impacts may be prevented by simple measures like educating the school staff, families and children about first aid for burn injuries. These impacts are subject to both punishment and compensation lawsuits. In this regard, expert witnesses and forensic reports are important to prevent miscarriages of justice.

Keywords: School accident, scald, burn, first aid, forensic reports

\section{Öz}

Okul ortamı, çocukların ebeveynlerinin gözetiminden çoğunlukla ilk kez ve uzun süreli uzak kaldıkları yerlerden biridir. Çocuklar okulda yanık gibi kazalardan yaralanabilir. Bu nedenle, güvenlik önlemleri alınmadığında savunmasız kalabilirler. Okulda meydana gelen travmanın ciddiyetini ve haşlanma yaralanmasının tıbbi yönünü tartışmayı amaçladık. Okul kantininde sıcak su dökülmesi sonucu yaralanan 7 yaşındaki erkek olguyu, literatür eşliğinde medikolegal açıdan değerlendirdik. Illk tıbbi kayıtlara göre vücut yüzeyinin \%30'unu kaplayan ikinci derece yanık olduğunu, tedavi sürecinde sepsis ve böbrek yetmezliği geliştiğini gördük. Üç yıl sonra adli rapor düzenlenmesi için yapılan muayenesinde doku kayıpları ve psikolojik semptomlar saptadık. Bulgularımız dikkat çekici bir şekilde kazaların bireylerde, ailelerinde kalıc fiziksel ve psikolojik zararlara ve toplum için önemli maliyetlere neden olabileceğini göstermiştir. Okul kazaları konusunda okul çalışanları, aileler ve çocuklara verilecek eğitimlerle ve alınacak basit önlemlerle kazalar önlenebileceği gibi fiziksel ve psikolojik olumsuz etkiler de azaltılabilecektir. Bu etkiler hem ceza hem de tazminat davasının konusudur. Bu bakımdan, uzman görüşleri ve adli raporlar, adaletin sağlanması için önemlidir.

Anahtar Kelimeler: Okul kazası, haşlanma yanığı, yanık, ilk yardım, adli rapor

\section{Introduction}

Accidents are defined as unfortunate incidents that cause sudden loss of life and property, and physical and psychological injuries that happen unexpectedly and unintentionally. ${ }^{1}$ Except for children $<1$ year old, accidents are one of the leading causes of child deaths and injuries. ${ }^{2.4}$ Insufficiency of understanding and perception of dangerous situations and failure in development of musculoskeletal system increase the risk of death and injury due to accidents especially in children $<5$ years old. ${ }^{3}$

In the pediatric age group, the most common causes of injury and death due to accidents are traffic accidents, falls, poisoning and burns. ${ }^{2-4}$ Among these reasons, burns are significant cause for morbidity and mortality, especially in children aged four years or below, and scalds are the most common type of burns. ${ }^{5-9}$ Scalds are burns with hot liquids. Generally, the width and depth of scalds are the most important factors that 
determine the prognosis and evaluate the severity of injuries in terms of forensic medicine. ${ }^{7,8}$ In addition to determining the severity of the injury, detecting permanent damages are also a part of the medicolegal evaluation. Thus, with the medicolegal evaluation, medical information and findings are used to solve legal problems.

Accidents may cause permanent physical and psychological damages in individuals, their families and also significant costs for the society. The extent of damage is possible to reduce by appropriate immediate first aid. In this case report, we discussed trauma severity and medicolegal aspects of a scald injury in the school.

\section{Case Report}

In April 2015, a 7-year-old male (born in 2007) was playing and running in a school canteen, when he tripped over a tea-urn cable and hot water spilled on his body. In records, no information whether first aid was provided or not or the specific first aid if provided in the school. The first medical records stated a second degree burn covering 30\% of the child's body. In follow-up process, multiple surgical debridement, escharotomies, skin autografts and artificial skin grafts and hyperbaric oxygen therapy were performed due to skin infection. Moreover, sepsis and renal insufficiency developed (Figure 1).

Three years after the accident, the child with his family applied to our department for his forensic report to prepare for penal proceedings. The examination showed a loss of subcutaneous adipose tissue and muscular tissue extending from the right armpit to the right side of the abdominal wall and keloids on the right and left thighs (Figure 2, 3).

No significant restriction was observed in the joint range of motion. Moreover, psychiatric symptoms such as social isolation, eye contact avoidance and speech reduction were observed. The treatment of the scald was said to be ongoing.

\section{Discussion}

Accidents may occur at every stage of life and everywhere. One of the places that accidents occur is the school environment where the children are mostly away from parental supervision for the first time and for a long period of time. School accidents are usually avoidable; however, they could be quite serious as in our case. It was stated that second degree burn covering approximately $30 \%$ of the patient's body surface at the first referral centre, with full-thickness skin and muscle losses in some areas during his treatment process.

In burns, some complications such as shock, sepsis, renal insufficiency, joint limitations and contractures and even malignancies may develop. ${ }^{7}$ In addition, psychiatric symptoms or disorders might be seen due to complications of the burn and long and challenging treatment process or the external appearance of deformities. ${ }^{7}$ Complications can occur, such as pain, amputations, neurological disorders and functional sequelae. Financial compensation for these damages is often sought by victims. At this point, the mission of the medicolegal evaluation is to attempt to assess the degree of permanent damages as justly as possible. In the medicolegal evaluation phase, it is important not to make a hasty judgement due to the slow maturation of scars over time. In order to make fair decisions in both the punishment and compensation lawsuits, the maturation of scars must be completed.

In our case, sepsis and renal insufficiency developed during the treatment period and diffuse hypertrophic scar tissues in the right axillary region and lumbar region were experienced, which had no significant limitation in the joint range of motion. In addition to physical findings, psychiatric symptoms were also observed. Appropriate and immediate first aid has importance in reducing complications and shortening the treatment process. In records, no information was reported about the any first aid in the school. Also, the family of the

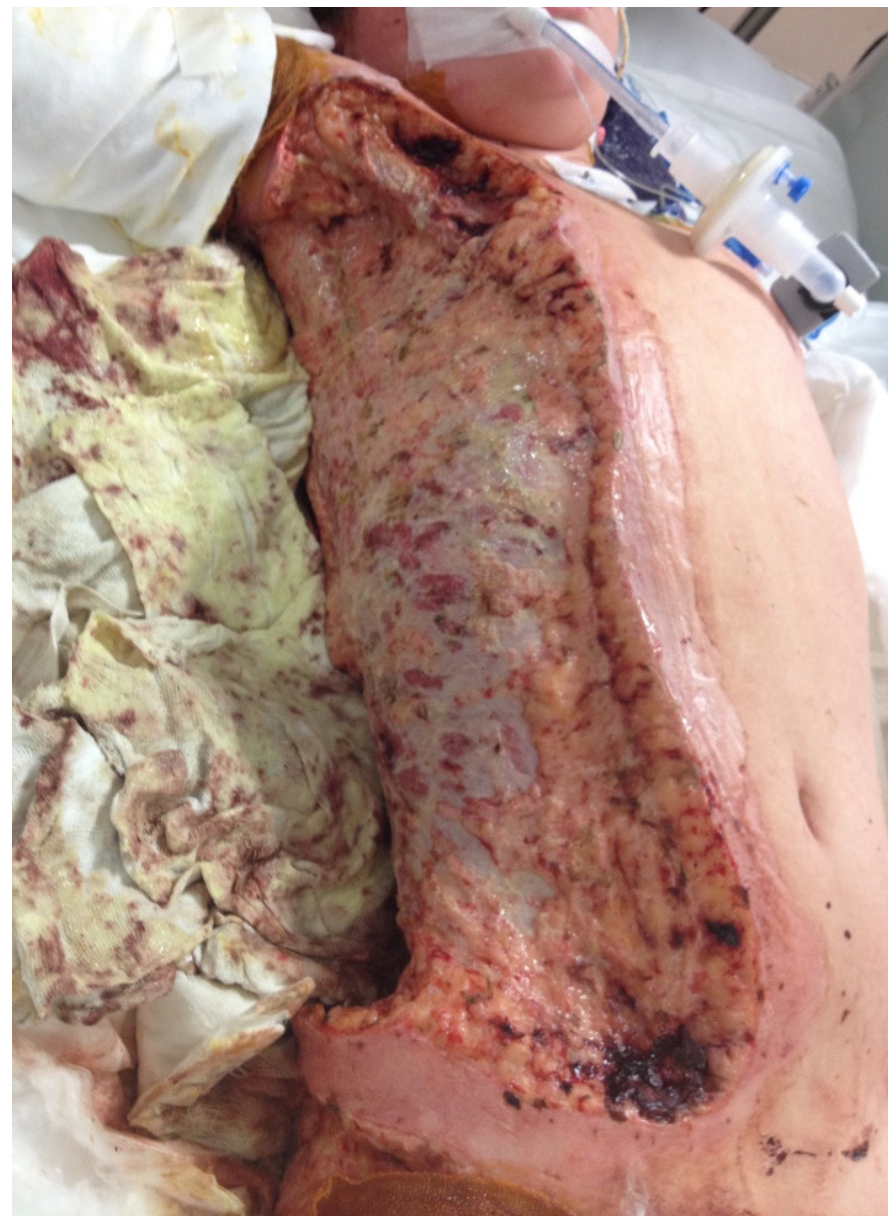

Figure 1. A view dated 22 May 2015, after a surgical debridement 

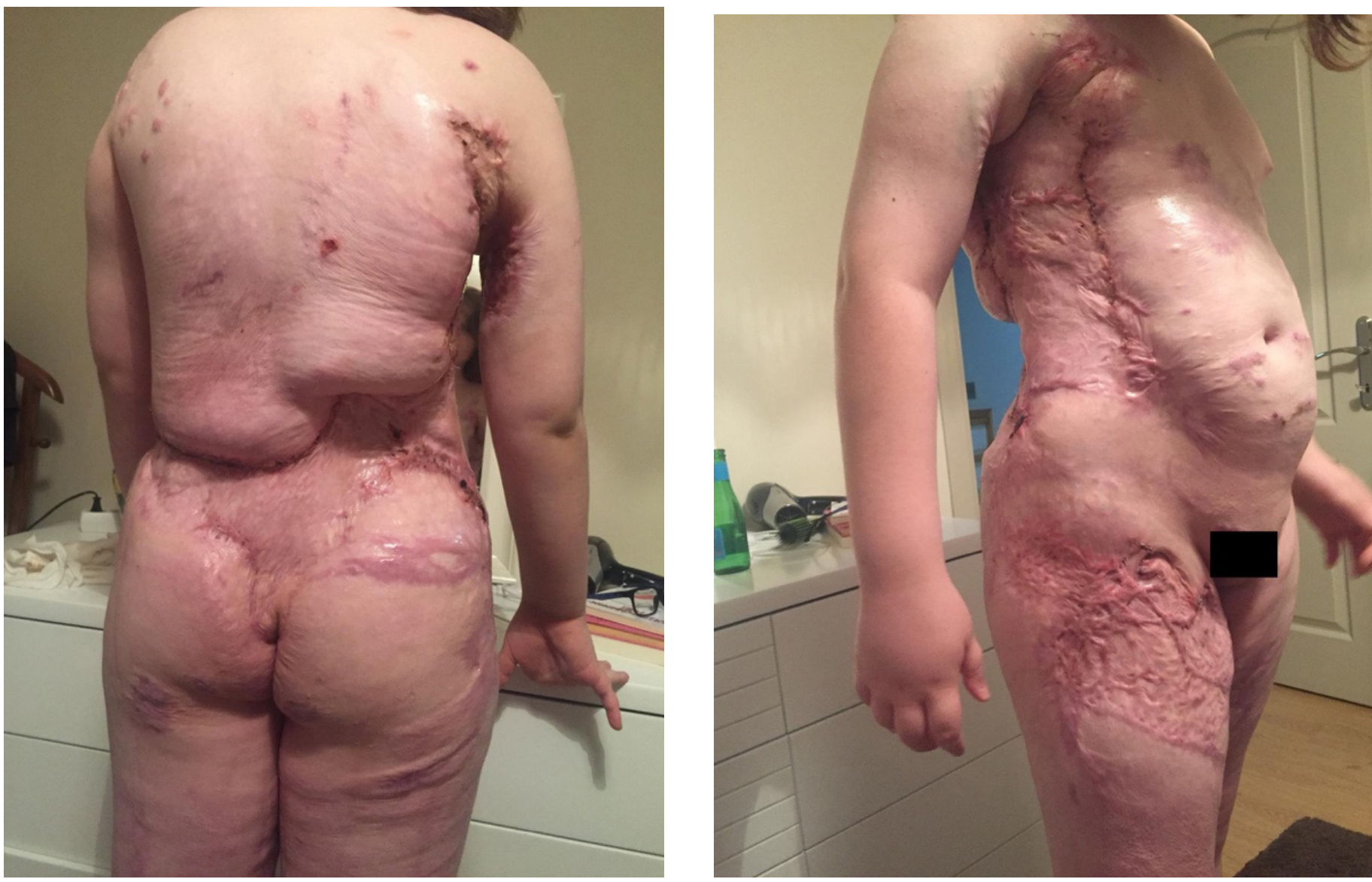

Figure 2, 3. Posterior and anterolateral views of burned areas (on September 2018)

child claims that first aid was not sufficiently made in the school and a delay was experienced in taking to the hospital.

The Turkish Standards Institute and the Ministry of National Education have been conducting studies in order to prevent injuries and mortal school accidents in recent days. These studies aimed to make risk analysis for schools and establish safety standards from schools' toilets, gyms, canteens and gardens. From the perspective of the present case, high risk areas where hot water boilers and power lines are common are in the school canteens that could be taken out from the free circulation areas for children. Moreover, security measures such as increasing the break time controls in canteens may greatly reduce the occurrence of such accidents. Also, risk for accidents may be reduced by giving trainings to students, teachers and parents from experts about the causes of accidents as well as its prevention. ${ }^{1}$ In addition, for a fast and effective first aid, trainings could be given to school employees. In terms of burns, it is a well-known fact that the first aid applied in the shortest time is important to reduce its effects and complications. Finally, it is considered that regular recording of accidents occurring in school and statistical evaluation of data in these records may be necessary for taking measures against risky situations.

\section{Conclusion}

In conclusion, a long, challenging and costly burn treatment process can cause physical, psychological and social repercussion and also a heavy financial burden on both the family and social resources. ${ }^{9}$ School officials have supervision obligations regarding children who are entrusted to them. Failure to perform this obligation is a forensic event. These damages are subjects to both punishment and compensation lawsuits. Therefore, it is important to find responsible person/s to determine whether accident precautions had been taken or not, and whether appropriate and timely first aid had been provided. In this regard, expert witnesses and reports are of great help. When the forensic reports are requested by the judicial authorities, determining the severity, findings and complications of the trauma and evaluating the permanent physical and psychiatric complications are important factors in the medicolegal evaluation. Paying attention to these basic elements may prevent miscarriages of justice. 


\section{Acknowledgements}

The manuscript is the original work of the authors. Authors received no financial support for the research, authorship and/or publication of this article. The manuscript has not been and will not be published elsewhere or submitted elsewhere for publication. This case report has been presented in $3^{\text {th }}$ International Congress on Child Protection as a poster at between the dates of September 30 to 3 October 2018, in Ordu, Turkey.

\section{Ethics}

Informed Consent: Written consent form was received.

Peer-review: Externally peer-reviewed.

\section{Authorship Contributions}

Concept: A.K., U.A., H.G., E.Ş., E.Ö.A., Design: A.K., U.A., H.G., E.Ş., E.Ö.A., Data Collection or Processing: A.K., U.A., H.G., E.S.., E.Ö.A., Analysis or Interpretation: A.K., U.A., H.G., E.Ş., E.Ö.A., Literature Search: A.K., U.A., H.G., E.S.., E.Ö.A., Writing: A.K., U.A., H.G., E.Ş., E.Ö.A.

Conflict of Interest: No conflict of interest was declared by the authors.

Financial Disclosure: The authors declared that this study received no financial support.

\section{References}

1. Akçay D, Yıldırımlar A. Investigation of Children's School Accident and Behavior of Their Parents Safety Measures. DEUHFED 2018;11:48-55.

2. İnanıcı MA, Birgen N. 0-5 Yaş Grubu Çocuk Ölümlerinin Adlî Tıp Boyutu. Adli Tıp Bülteni. 2001;6:70-5.

3. Demir U, Aşırdizer M, Etli Y, Kartal E, Gümüş O, ve ark. Analysis of accidental deaths of children under five years of age. J For Med. 2017;31:17-25

4. Dönmez $H$, Çalışkan $C$, Arberk OK, Ünlü $H$, Biçer BK, ve ark. Türkiye'de 7-14 yaş grubu çocuklarda yaralanmalara ilişkin bir değerlendirme. Turkish J Pediatr Dis. 2018;4:236-42.

5. Fomukong $\mathrm{NH}$, Mefire $\mathrm{AC}$, Beyiha $\mathrm{G}$, Lawrence $\mathrm{M}$, Edgar MML, Nkfusai NC, Cumber SN. Predictors of mortality of pediatric burn injury in the Douala General Hospital, Cameroon. Pan Afr Med J. 2019:1:189.

6. Oseni OG, Olamoyegun KD, Olaitan PB. Paediatric burn epidemiology as a basis for developing a burn prevention program. Ann Burns Fire Disasters. 2017;30:247-9.

7. World Report on child injury prevention, Burns, Chapter 4, https:// www.who.int/violence_injury_prevention/child/injury/world_ report/Burns.pdf, (accessed 24 December 2018).

8. Garcia-Espinoza JA, Aguilar-Aragon VB, Ortiz-Villalobos EH, Garcia-Manzano RA, Antonio BA. Burns:Definition, Classification, Pathophysiology and Initial Approach. Int J Gen Med. 2020;5:5.

9. Al-Hajj S, Pike I, Oneissi A, Zheng A, Abu-Sittah G. Pediatric Burns Among Refugee Communities in Lebanon: Evidence to Inform Policies and Programs. J Burn Care Res. 2019;40:769-75. 